\title{
Comment
}

\section{Environmental Injustice: The (Unaddressed) Case of Toxic Waste Disposal in the Global South $^{*}$}

I. The 'Management' of Toxic Waste: A Normative Dilemma

II. Outsourcing Health and Environmental Harms in a 'Post-Basel World'

III. The Basel Convention: Regulating the Trade of Toxic Waste in a Homogenous World

IV. Responding to the Regulatory Gap: A Human Rights Approach

V. Activating Human Rights in Transboundary Flows of Toxic Waste

VI. Conclusion

\section{The 'Management' of Toxic Waste: A Normative Dilemma}

'The ability to manufacture and export toxic substances banned from use domestically is one, albeit large, element of how States have institutionalized externalities through discriminatory national laws and an outdated system of global governance for chemicals and wastes', writes the former Special Rapporteur on toxics and human rights, Baskut Tuncak (Special Rapporteur), in a recent report on the implications of hazardous waste on human rights and the environment. ${ }^{1}$ For many years, states of the Global North have been exporting highly hazardous substances and wastes, whose use they have strictly prohibited under their own laws for health and environmental reasons, to countries in the Global South. ${ }^{2}$ The Special Rapporteur condemns the practice of the transboundary movement of hazardous waste as profoundly discriminatory and as another manifestation of 'environmental in-

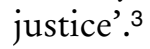

* I am very grateful to Achilles Skordas for his insightful feedback during the editing process and his careful reading of the drafts of this comment. I would also like to thank Anne Peters and Bajar Scharaw for their valuable remarks.

1 UNGA, Report of the Special Rapporteur on the implications for human rights of the environmentally sound management and disposal of hazardous substances and wastes, 5 August 2020 (UN Doc A/75/290), para. 9.

2 Report Special Rapporteur (n. 1), para. 8.

3 Report Special Rapporteur (n. 1), paras 7, 11. 
The former Special Rapporteur's statement reveals the normative dilemma and challenges associated with the regulatory framework on transboundary movements of toxic waste. First, the pertinent international rules provide for the 'management'4 of hazardous waste flow across borders from the Global North to the Global South. Toxic waste dumping results in a wide range of human rights abuses and damage to the environment. Importantly, it also entrenches and amplifies pre-existing socio-economic inequalities in the countries of the Global South. ${ }^{5}$ Second, as we will see, the regulatory framework is based on a misleading inter-state geography that is limited to NorthSouth relations and ignores the circulation of toxic waste in other regions, especially within the Global South. This comment aims to show the deficiencies of a simplistic and general fixation on regulating the cross-border movements of toxic waste on the basis of an inter-state geography. As I will argue, what is needed instead is an individualistic, human rights-based approach, which is better suited to addressing the human rights abuses that result from toxic waste trade.

\section{Outsourcing Health and Environmental Harms in a 'Post-Basel World'}

Environmental injustices resulting from the cross-border trade of toxic waste remain a deeply rooted characteristic of the global economy. ${ }^{6}$ International law has developed several regulatory frameworks to respond to these injustices caused by waste business. The main regulatory instrument that lies at the heart of international environmental law is the Basel Convention on the Control of Transboundary Movements of Hazardous Wastes and their Disposal (Basel Convention), adopted in 1989.7 The Convention manages the transboundary movement of toxic waste from 'developed' to 'developing' countries. ${ }^{8}$ But the detrimental impact of toxic

4 Olivier Barsalou and Michael Hennessy Picard, 'International Environmental Law in an Era of Globalized Waste', Chinese Journal of International Law 17 (2018), 887-906 (898).

5 Report Special Rapporteur (n. 1), paras 8, 11.

6 Julia Dehm and Adil Hasan Khan, 'North-South Transboundary Movement of Hazardous Wastes - the Basel Ban and Environmental Justice', in: Philippe Cullet and Sujith Koonan (eds), Research Handbook on Law, Environment and the Global South (Cheltenham/Northampton: Edward Elgar Publishing 2019), 109-137 (109).

7 Basel Convention on the Control of Transboundary Movements of Hazardous Wastes and their Disposal, 22 March 1989, 1673 UNTS 57 (Basel Convention). 188 States Parties, including the EU but not the US, have acceded to the Basel Convention so far.

8 Barsalou and Picard (n. 4), 898. See also Josh Lepawsky, 'Are We Living in a Post-Basel World?', Area 47 (2015), 7-15 (9). 
waste trade on individuals' human rights has also given rise to a 'human rights paradigm' by virtue of states' pre-existing human rights obligations, under the respective treaties, to effectively prevent and minimise exposure to hazardous substances. ${ }^{9}$

The regulatory framework of the Basel regime contains a number of significant loopholes that render it ineffective in addressing the systemic issues underlying the trade of toxic waste. In a 'post-Basel world', as Josh Lepawsky has pointed out, these systemic issues arise from a 'linear conception' claiming that developed states dump hazardous substances in developing countries - a conception at the very core of the Basel Convention -, which no longer holds true. ${ }^{10}$ Instead, toxic waste trade is a "complex story'11 involving networks of waste brokers and collaborators operating in decentralised and uncontrolled settings all over the globe. Moreover, the data analysis on trade in electronic waste (e-waste) reveals that toxic waste trade has now expanded not only between developed and developing countries but also intra-regionally in the Global South, between developing countries themselves. ${ }^{12}$

In making this point, I do not contest the fact that much of the developed world's toxic waste ends up in Latin America, Africa, and, more recently, in South East Asia. ${ }^{13}$ As a result, 'poor' countries in the Global South endure a greater share of the harmful effects of hazardous substances, even though these countries often lack the resources and technical knowledge for waste processing. ${ }^{14}$ Indeed, empirical studies confirm that toxic substances are systematically dumped in particular geographic locations, such as those where poor persons, indigenous peoples, or racial and ethnic minorities reside and work. ${ }^{15}$ However, I argue that the negative externalities of toxic

9 Dehm and Khan (n. 6), 112. See also HRC, Report of the Special Rapporteur on the implications for human rights of the environmentally sound management and disposal of hazardous substances and wastes on his mission to Denmark and Greenland, 14 November 2018 (UN Doc A/HRC/39/48/Add.2), para. 81 (a).

10 Lepawsky (n. 8); Josh Lepawsky and Chris McNabb, 'Mapping International Flows of Electronic Waste’, The Canadian Geographer 54 (2010), 177-195 (190).

11 Lepawsky and McNabb (n. 10), 184.

12 Josh Lepawsky, 'The Changing Geography of Global Trade in Electronic Discards: Time to Rethink the E-Waste Problem', The Geographical Journal 181 (2015), 147-159 (147). For trade of e-waste in particular, see Karin Lundgren, 'The Global Impact of E-Waste: Addressing the Challenge', International Labour Organization, Geneva 2012.

13 Jessica von Blazekovic, Indonesien schickt tonnenweise deutschen Müll zurück, Frankfurter Allgemeine Zeitung, 4 July 2019, <https://www.faz.net/aktuell/wirtschaft/indonesienschickt-deutschland-tonnenweise-muell-zurueck-16268553.html>. See also Report Special Rapporteur (n. 1), para. 8.

14 Report Special Rapporteur (n. 1), paras 3, 10.

15 Report Special Rapporteur (n. 1), para. 11. See also Hugh J. Marbury, 'Hazardous Waste Exportation: The Global Manifestation of Environmental Racism', Vand. J. Transnat'l L. 28 (1995), 251-294 (292). 
waste streams emanating from other countries and brokers of the Global South also affect these 'poor' countries and their populations much like the toxic waste streams from countries of the Global North. ${ }^{16}$ From a legal perspective, this demands activating a human rights approach to transboundary movements of toxic waste that is equipped to deal with the 'geographical imaginaries'17 built into the regulatory framework of the Basel Convention.

\section{The Basel Convention: Regulating the Trade of Toxic Waste in a Homogenous World}

Initially, the Basel Convention was intended to bring about a 'legal environmental revolution' with regard to transboundary shipments of toxic waste. It sought to end 'toxic colonialism', as reflected in several contamination cases involving foreign companies in the Global South at the time. ${ }^{18}$ During the treaty negotiations, the North-South tensions over the regulatory rationale underlying the Basel Convention became apparent. States of the Global South advocated a complete ban on toxic waste trade from other states, most notably from developed countries. ${ }^{19}$ States of the Global North, on the other hand, expressly opposed such a ban for economic reasons. ${ }^{20} \mathrm{~A}$ number of Southern states with strong recycling industries, in particular India and Pakistan, fearing that the proposed ban would be detrimental to their national economies, also supported the proposals of the Global North. ${ }^{21}$ Consequently, the Basel Convention's adoption reflected the interests of the developed countries by regulating rather than banning the trade of hazardous waste for purposes of recycling

16 See also Lepawsky (n. 8), 7.

17 Lepawsky (n. 8), 8.

18 Alan Andrews, 'Beyond the Ban - Can the Basel Convention Adequately Safeguard the Interests of the World's Poor in the International Trade of Hazardous Waste?', Law, Environment and Development Journal 5 (2009), 167-184 (169). See also Laura A. Pratt, 'Decreasing Dirty Dumping? A Reevaluation of Toxic Waste Colonialism and the Global Management of Transboundary Hazardous Waste', William and Mary Environmental Law and Policy Review 35 (2011), 581-623.

19 Zada Lipman, 'Trade in Hazardous Waste', in: Shawkat Alam, Sumudu Atapatu, Carmen G. Gonzalez and Jona Razzaque (eds), International Environmental Law and the Global South (Cambridge: Cambridge University Press 2015), 256-276 (260).

20 Dehm and Khan (n. 6), 116.

21 Jonathan Krueger, 'The Basel Convention and the International Trade in Hazardous Wastes', in: Olav Schram Stokke and Oystein B. Thommessen (eds), Yearbook of International Cooperation on Environment and Development 2001/2002 (London: Earthscan Publications 2009), 43-51 (45); Lipman (n. 19), 260. 
or disposal. ${ }^{22}$ The Basel Convention's core objective is thus the 'efficient management' ${ }^{\prime 3}$ of the collection, transport, and, most importantly, disposal of toxic waste. ${ }^{24}$

Since its adoption in 1992, it has become evident that the Basel Convention suffers from several unique 'weaknesses that undermine its effectiveness', ${ }^{25}$ beyond the well-known challenges that are latent in international environmental treaties in general, such as weak compliance and enforcement mechanisms. ${ }^{26}$ These particular issues associated with the market-based rationale of the Basel regime further deepen the existing North-South and, as we will see, South-South disparities. Above all, they undermine the human rights of those affected in the name of the 'management market' for toxic waste. ${ }^{27}$ For instance, a fundamental criticism holds that the legal definition of 'hazardous waste' in the Basel Convention is ambiguous. ${ }^{28}$

But the landmark amendment to the Basel Convention (Ban Amendment), which was adopted by decision III/1 at the Third Meeting of the Conference of the Parties in 1995 and entered into force in 2019, created a crucial loophole. ${ }^{29}$ Given the deficiencies of the Basel Convention, the Ban Amendment prohibits the transboundary movements of hazardous wastes from Annex VII countries to non-Annex VII countries that are parties to the Basel

22 Dehm and Khan (n. 6), 116; Lipman (n. 19), 261. See also UNHCR, Opening Remarks, UN Special Rapporteur on toxics and human rights, Marcos A. Orellana at the 75th Session of the UN General Assembly, 27 October 2020, in which the Special Rapporteur draws attention to the legalisation of toxic waste dumping, stating that victims of this practice are 'legally poisoned' by 'permissible limits' of toxic exposures that do not account for human rights protections.

23 Article 4 (2) (d) of the Basel Convention; Barsalou and Picard (n. 4), 898.

24 For a general overview of the Basel Convention, see Juliette Voinov Kohler, 'The Basel Convention on the Control of Transboundary Movements of Hazardous Wastes and their Disposal 1989', in: Malgosia Fitzmaurice, Attila Tanzi and Angeliki Papantoniou (eds), Multilateral Environmental Treaties (Cheltenham/Northampton: Edward Elgar Publishing 2017), 331-342.

25 Lipman (n. 19), 265.

26 Voinov Kohler (n. 24), 340.

27 Barsalou and Picard (n. 4), 888.

28 Voinov Kohler (n. 24), 332-334.

29 The Ban Amendment was originally adopted as Decision II/12 at the Second Meeting of the Conference of the Parties in 1994, see UNEP, Report of the Second Meeting of the Conference of the Parties to the Basel Convention on the Control of Transboundary Movements of Hazardous Wastes and their Disposal, Decision II/12, 25 March 1994 (UN Doc UNEP/CHW/2/30). In 1995, at the Third Meeting of the Conference of the Parties, the contracting parties to the Basel Convention adopted a follow-up Decision III/1 as an amendment to the Basel Convention, see UNEP, Report of the Third Meeting of the Conference of the Parties to the Basel Convention on the Control of Transboundary Movements of Hazardous Wastes and their Disposal, 28 November 1995 (UN Doc UNEP/CHW.3/35). For an overview of the development of the Ban Amendment, see $<$ http://www.basel.int $>$. 
Convention..$^{30}$ Accordingly, at the centre of the Ban Amendment is the addendum to the Basel Convention known as Annex VII, which divides the contracting parties to the Basel Convention into two groups of countries. ${ }^{31}$ While the first group is composed of members of the Organisation for Economic Co-operation and Development (OECD), the European Union (EU), and Liechtenstein, the second group includes all other signatory states to the Basel Convention, including 'developing countries' of the Global South. ${ }^{32}$ The Ban Amendment prohibits all transboundary movements of hazardous wastes destined for final disposal, recovery, or recycling operations from OECD to non-OECD countries. ${ }^{33}$

The Ban Amendment has divided the parties to the Basel Convention into two blocs, namely developed and developing countries, in order to prevent the North-South export of toxic waste. ${ }^{34}$ The process of negotiating the Ban Amendment was also marked by tensions that exposed the inequalities within the Global South. Neither the developed countries nor some of the important developing countries supported the Ban Amendment. ${ }^{35}$

Of particular concern, however, is that the Basel Convention continues to allow transboundary transfers of toxic waste between non-Annex VII countries, namely between developing countries. ${ }^{36}$ The Basel regime, based on an 'imaginary geography of vulnerability', ${ }^{37}$ treats all developing countries not subject to Annex VII as a monolithic and homogenous bloc, without taking into account the structural diversity that exists among these countries, for example in terms of political power, wealth, or technological capacities. ${ }^{38}$ Under the Ban Amendment, developing countries are to be protected solely from transboundary movements of hazardous wastes from developed countries.

The distribution of waste inevitably has a 'spatial aspect'. ${ }^{39}$ Recent research shows a fundamental shift in the geographic dimension of global commodity flows and value chains. ${ }^{40}$ Emerging economies play an increasingly important

30 Dehm and Khan (n. 6), 115; Lepawsky and McNabb (n. 10), 179.

31 Lepawsky (n. 8), 9.

32 Annex VII to the Basel Convention. See also UNEP, Decision III/1 (n. 29).

33 <http://www.basel.int $>$. See also Report Special Rapporteur (n. 1), para. 4.

34 Lepawsky (n. 8), 11.

35 Andrews (n. 18), 183-184.

36 Lepawsky and McNabb (n. 10), 179.

37 Lepawsky (n. 12), 152.

38 Lepawsky and McNabb (n. 10), 179.

39 Zsuzsa Gille, From the Cult of Waste to the Trash Heap of History: The Politics of Waste in Socialist and Postsocialist Hungary (Bloomington/Indianapolis: Indiana University Press 2007), 20.

40 Gary Gereffi, 'Global Value Chains in a Post-Washington Consensus World', Review of International Political Economy 21 (2014), 9-37 (28); Lepawsky (n. 8), 7. 
role in international trade, especially within the Global South. ${ }^{41}$ China and India in particular have now become important actors in the trade of toxic waste. ${ }^{42}$ However, under the Basel Convention, signatory countries such as China and India, but also Bangladesh or Kenya, which are not among those listed in Annex VII, are considered equally disadvantaged and at risk in terms of transboundary movements of hazardous wastes from developed countries. ${ }^{43}$ But they are not themselves considered a risk for moving such wastes to other countries of the Global South. ${ }^{44}$

In this sense, neither the Basel Convention nor the Ban Amendment overcome the significant systemic problems that underlie the governance of toxic waste trade, which disproportionately favours the interests of the Global North, but also of powerful states of the Global South, over the interests of poor communities within these states and of the Global South as a whole. Undoubtedly, systemic problems are underpinned by asymmetrical power and inequalities that are generated and fostered by marketdriven rationales in light of a global economy that predominantly favours wealthier states. However, the Basel regime does not take into account the power imbalances as well as political and economic disparities between developing countries that shape the trade of hazardous substances within the Global South. ${ }^{45}$

\section{Responding to the Regulatory Gap: A Human Rights Approach}

I argue that human rights have a crucial role to play in closing the regulatory gap created by the Basel Convention and the subsequent Ban Amendment, which are based on outdated notions of transboundary flows of toxic waste and therefore ignore significant geographies of the toxic waste trade. As in many areas of international law, the field of toxic waste trade calls for a human rights approach. ${ }^{46}$ The Special Rapporteur has operationalised a human rights approach and addressed the implications of transboundary movements of toxic waste for human rights in several reports, particularly concerning the right to life and physical integrity, non-discrimination,

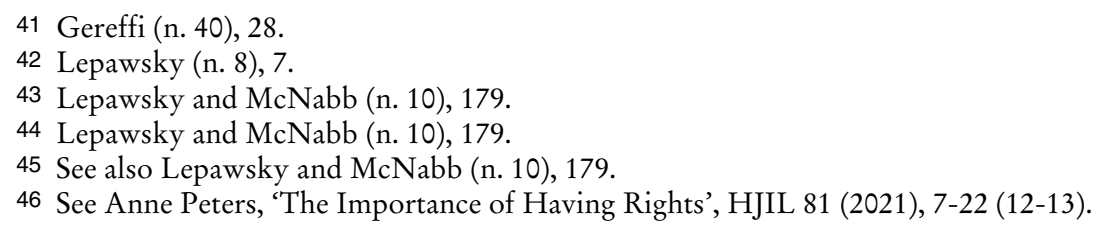


the right to health, and the right to information and to an effective remedy. ${ }^{47}$ Moreover, he has drawn attention to the global context of the trade of hazardous waste by stressing that 'what originated from the problem of waste flows from wealthier to poorer countries is now illuminated as a situation of the most vulnerable suffering the insidious impacts of toxic substances through the life cycle of consumption and production, both within and between borders'. ${ }^{48}$

Given recent criticism regarding human rights in general, ${ }^{49}$ it is not surprising that some scholars claim that human rights cannot adequately deal with the problem of transboundary flows of hazardous waste and their adverse impact on human rights and the environment, especially as far as the distributional dimension of the issue is concerned.50 While I acknowledge that toxic waste trade and human rights may be in conflict, ${ }^{51}$ new developments at the international level indicate that international human rights law has the potential to protect our globe's most vulnerable populations against the harmful effects of transboundary movements of toxic waste. Hence, applying human rights to the trade of toxic waste in its North-South and South-South dimensions is not an empty gesture. Rather, it is the upshot of the need to systematically mainstream existing human rights mechanisms, procedural rules, and positive practices for global waste trade, which could contribute to filling the gaps left by the regulatory framework of the Basel regime.

\section{Activating Human Rights in Transboundary Flows of Toxic Waste}

A human rights approach to transboundary movements of hazardous waste is based on the premise that all states that are parties to universal human rights treaties are bound by their human rights obligations under

47 See, e.g. on the human rights implications of the right to information on hazardous substances and wastes, HRC, Report of the Special Rapporteur on the implications for human rights of the environmentally sound management and disposal of hazardous substances and wastes, Baskut Tuncak, 8 July 2015 (UN Doc A/HRC/30/40).

48 Report Special Rapporteur (n. 1), para. 85 (emphasis added).

49 Peters (n. 46), 15-18.

50 Dehm and Khan (n. 6), 113.

51 Carmen Gonzalez, 'Environmental Justice, Human Rights, and the Global South', Santa Clara Journal of International Law 13 (2015), 151-195 (153); Dehm and Khan (n. 6), 113. See also, e.g. Lorand Bartels, 'Trade and Human Rights', in: Daniel Bethlehem, Isabelle Van Damme, Donald McRae and Rodney Neufeld (eds), The Oxford Handbook of International Trade (Oxford: Oxford University Press 2009), 571-596. 
those treaties, in particular under the International Covenant on Civil and Political Rights (ICCPR) and the International Covenant on Economic, Social and Cultural Rights (ICESCR). ${ }^{52}$ These and other human rights treaties provide for legal obligations and mechanisms to respond to the negative externalities caused by the transboundary disposal of toxic waste.

States' extraterritorial human rights obligations, arising from the ICCPR or the ICESCR among others, constitute an important human rights-related tool, which can activate and operationalise a human rights approach with respect to the cross-border disposal of toxic waste. The Special Rapporteur has noted that the dumping of toxic waste in foreign countries 'serves as another illustration of the importance of States being accountable for their extraterritorial obligations', ${ }^{53}$ highlighting the relevance of incorporating extraterritorial human rights obligations into the global governance system for toxic waste. This observation coincides with legal and policy developments at the international level, where the protection of human rights increasingly extends to cases of extraterritorial effects triggered by policy decisions adopted by states within their territories. ${ }^{54}$ While the extraterritorial application of human rights, in particular of civil and political rights, was developed primarily by the European Court of Human Rights (ECtHR) in regard to very specific cases of military or police actions by states in other countries, ${ }^{55}$ international human rights bodies have begun to address the extraterritorial application of human rights in a global context and to develop new doctrines applicable to the negative externalities of states' actions or omissions that infringe not only civil and political rights but also socio-economic rights. 56 Even if many legal questions remain open and controversial, extraterritorial obligations increasingly present an influential tool to embrace states' crossborder human rights responsibilities, for example regarding human rights

52 International Covenant on Civil and Political Rights, 16 December 1966, 999 UNTS 171 (ICCPR); International Covenant on Economic, Social and Cultural Rights, 16 December 1966, 993 UNTS 3 (ICESCR).

53 Report Special Rapporteur (n. 1), para. 8.

54 For economic and social rights, see Elif Askin, 'Economic and Social Rights, Extraterritorial Application' in: Rüdiger Wolfrum (ed.), MPEPIL (online edn, Oxford: Oxford University Press 2019).

55 See, e.g. ECtHR (Grand Chamber), Al-Skeini and others v. The United Kingdom, judgment of 7 July 2011, no. 55721/07.

56 See, e. g. HRC, General Comment No. 36 (Article 6: right to life), 3 September 2019 (UN Doc CCPR/C/GC/36) para. 22: 'They must also take appropriate legislative and other measures to ensure that all activities taking place in whole or in part within their territory and in other places subject to their jurisdiction, but having a direct and reasonably foreseeable impact on the right to life of individuals outside their territory, including activities undertaken by corporate entities based in their territory or subject to their jurisdiction [...]' (emphasis added). 
infringements resulting from toxic waste disposal. Extraterritorial obligations are geographically independent, that is, they apply not only to states of the Global North (although discussions of these obligations primarily focus on this group of states) but also to countries of the Global South, to the extent that the prerequisites for their application are met.

International human rights law is also a useful tool in other regards. There are a number of further instruments and mechanisms that can be applied to the transboundary movements of toxic waste, which I cannot elaborate on here. At the international level, for instance, states' due diligence obligations are becoming increasingly relevant with regard to the activities of non-state actors. ${ }^{57}$ Due diligence obligations derive from the human rights-related duty to protect, which requires states to take appropriate measures to prevent or mitigate human rights violations caused by private actors. ${ }^{58}$ In the area of toxic waste, however, due diligence is particularly relevant with regard to waste brokers, who typically operate through complex, dynamic networks in different countries. Also worth noting are buman rights impact assessments, which require states to evaluate the transboundary impact of their laws, policies, or state practices on human rights..$^{59}$ Remarkably, both due diligence obligations and human rights impact assessments have their 'roots' in international environmental law and can therefore be fruitfully applied to the transboundary movement of toxic waste and its negative impact on human rights and the environment. ${ }^{60}$

These and other human rights obligations and mechanisms, albeit some of them not yet fully developed or still in the process of emergence, are indeed essential tools that should be integrated into the regulatory framework governing the trade of toxic waste. To overcome the deadlock of the Basel

57 For a general discussion on due diligence in international law, see notably Heike Krieger, Anne Peters and Leonhard Kreuzer (eds), Due Diligence in the International Legal Order (Oxford: Oxford University Press 2020).

58 See Björnstjern Baade, 'Due Diligence and the Duty to Protect Human Rights', in: Krieger, Peters and Kreuzer (n. 57), 92-108.

59 UNGA, Final draft of the guiding principles on extreme poverty and human rights, submitted by the Special Rapporteur on extreme poverty and human rights, Magdalena Sepúlveda Carmona, 18 July 2012 (UN Doc A/HRC/21/39), adopted by HRC resolution 21/11, 18 October 2012 (UN Doc A/HRC/RES/21/11), para. 92: 'As part of international cooperation and assistance, States have an obligation to respect and protect the enjoyment of human rights, which involves avoiding conduct that would create a foreseeable risk of impairing the enjoyment of human rights by persons living in poverty beyond their borders, and conducting assessments of the extraterritorial impacts of laws, policies and practices.'

60 See Anne Peters, 'Global Constitutionalism: The Social Dimension', in: Takao Suami, Anne Peters, Dimitri Vanoverbeke and Matthias Kumm (eds), Global Constitutionalism from European and East Asian Perspectives (Cambridge: Cambridge University Press 2018), 277-350 (322-324). 
regime, a human rights approach is key to protecting vulnerable populations and the environment from exposure to hazardous substances, regardless of the region where toxic waste is dumped and where those affected live.

\section{Conclusion}

Many years ago, in her book Silent Spring, Rachel Carson warned: 'If we are going to live so intimately with these chemicals - eating and drinking them, taking them into the very marrow of our bones - we had better know something about their nature and their power.'61 While the dangers of exposure to toxic waste have been known for decades, the impact of toxic waste on poor communities around the world continues to grow faster than ever. ${ }^{62}$ As the Special Rapporteur has shown, exposure to hazardous waste interferes with numerous human rights and contaminates our bodies and our planet.

This comment sought to highlight the dark sides of the regulation of 'waste management' and its underlying logic of 'geographic imaginaries'. ${ }^{63}$ Such regulation has failed to protect individuals against human rights abuses and environmental damage caused by practices of toxic waste disposal, which includes developed countries dumping waste in developing countries and, just as importantly, various countries of the Global South doing so between themselves. While partly still imperfect, a human rights approach offers a valid solution - albeit too radical for some - to curtail the destructive effects of hazardous substances and to end the negative externalities caused by the global trade in toxic waste.

Elif Askin

61 Rachel Carson, Silent Spring (Boston/New York: Houghton Mifflin Company 1962), 17.

62 UNGA, Report of the Special Rapporteur on the implications for human rights of the environmentally sound management and disposal of hazardous substances and wastes, Baskut Tuncak, 7 October 2019 (UN Doc A/74/480), para. 1.

63 Lepawsky (n. 8), 7. 
